December 2009

\title{
The International Criminal Court, the Security Council, and the Politics of Impunity in Darfur
}

Victor Peskin

Follow this and additional works at: https://digitalcommons.usf.edu/gsp

\section{Recommended Citation}

Peskin, Victor (2009) "The International Criminal Court, the Security Council, and the Politics of Impunity in Darfur," Genocide Studies and Prevention: An International Journal: Vol. 4: Iss. 3: Article 4.

Available at: https://digitalcommons.usf.edu/gsp/vol4/iss3/4

This Articles is brought to you for free and open access by the Open Access Journals at Digital Commons @ University of South Florida. It has been accepted for inclusion in Genocide Studies and Prevention: An International Journal by an authorized editor of Digital Commons @ University of South Florida. For more information, please contact digitalcommons@usf.edu. 


\title{
The International Criminal Court, the Security Council, and the Politics of Impunity in Darfur
}

\author{
Victor Peskin \\ School of Politics and Global Studies, Arizona State University
}

This article analyzes the political challenges confronting the International Criminal Court (ICC) in its efforts to bring war crimes suspects to trial in connection with mass atrocities committed in the Darfur region of Sudan. It chronicles and examines the battles over cooperation between the ICC and the defiant Sudanese government that have forestalled the handover of suspects such as Sudanese president Omar Hassan al-Bashir. It also seeks to explain why the Security Council, in its ambivalence toward the ICC, has not vigorously pressed Sudan to fulfill its legal obligation to cooperate.

Key words: International Criminal Court, Darfur, war crimes, Security Council

\section{Introduction}

In its difficult early years, the International Criminal Tribunal for the Former Yugoslavia (ICTY) was likened by its founding chief justice to a giant without arms and legs. ${ }^{1}$ The analogy sought to describe the paradoxical nature of the ICTY insofar as it is both a powerful institution-given its authority to prosecute high-level government officials-and a powerless one-given its lack of any enforcement powers. Today's ad hoc international tribunals and the permanent International Criminal Court (ICC) have no direct power to compel states to arrest war crimes suspects and hand them over for trial. State cooperation is as vital for tribunals as it is resisted by governments complicit in mass atrocities. Although the tribunals and the ICC prosecute individuals only, governments and their leaders often perceive such trials as an assault on the state itself. Nowhere is this more evident than when a head of state is targeted, as is now occurring with the ICC's arrest warrant for Sudan's Omar Hassan al-Bashir on charges of war crimes and crimes against humanity in Darfur.

Without power to enforce, the contemporary war crimes tribunals would seem to lack any leverage whatsoever to bring recalcitrant states into compliance. However, the hard-won success of the ICTY - which has obtained custody of scores of suspectsdemonstrates that today's international courts can mount effective challenges against targeted states. For tribunals, garnering support from key international actors, or "surrogate enforcers," 2 is the key to wresting cooperation from a recalcitrant state. In the face of international pressure, targeted states such as Serbia and Sudan often mobilize their foreign policy machinery to thwart the tribunals. To counter the tribunal's attempt to delegitimize the state as an international outlaw, the state seeks to knock the tribunal off its moral pedestal by highlighting its real and perceived shortcomings. ${ }^{3}$

Victor Peskin, "The International Criminal Court, the Security Council, and the Politics of Impunity in Darfur," Genocide Studies and Prevention 4, 3 (December 2009): 304-328. (C) 2009 Genocide Studies and Prevention. doi:10.3138/gsp.4.3.304 
When it comes to the ICC's quest for cooperation from Sudan, the battle for international intervention has become even more contentious, particularly given the Security Council's authority to suspend controversial cases. Under Article 16 of the Rome Statute, the ICC's founding document, the Security Council can actually halt ICC cases for renewable one-year periods when they are determined to pose a threat to international peace and security. Thus, even as the ICC looks to the Security Council to press Sudan to comply with its obligation to cooperate, the Sudanese government has-in the aftermath of the chief prosecutor's application for an arrest warrant for President al-Bashir in July 2008-tried to push the Council to invoke Article 16 by arguing that the ICC is a spoiler of the peace process in Darfur. Long before the chief prosecutor's bid for al-Bashir's arrest warrant, the Sudanese government sought to play up the damaging consequences of international justice in Darfur by discouraging international support for the ICC and mobilizing African and Arab allies to magnify the government's opposition to the Court. Ever since ICC Chief Prosecutor Luis Moreno-Ocampo announced his intention to prosecute al-Bashir-and ever since the ICC pre-trial chamber ${ }^{4}$ issued a warrant for al-Bashir's arrest on 4 March 2009the Sudanese government has been increasingly emphatic in its warnings about the hazards posed by The Hague-based ICC.

To counter Sudan's framing of the issue, Moreno-Ocampo has argued that a failure by the international community to back the ICC's pursuit of al-Bashir and two other Sudanese suspects will only embolden Khartoum's criminality. Unless al-Bashir is forced to account for his alleged crimes, asserts Moreno-Ocampo, the Sudanese president will be in a position to direct more violence against vulnerable civilians in Darfur. ${ }^{5}$ When it issued the warrant for al-Bashir's arrest in March 2009, the ICC pre-trial chamber granted the prosecutor's request for war crimes and crimes against humanity charges, but rejected his request for genocide charges. The prosecutor subsequently filed an appeal of the pre-trial chamber's rejection of the genocide counts. ${ }^{6}$ It is too early to determine when or even whether al-Bashir and two other Sudanese suspects tied to state violence in Darfur will ever face trial at the ICC. Their fate will depend in no small part on whether Sudan or the ICC wins the peace versus justice debate by drawing the Security Council, the African Union, and other key international actors to its side.

A decade and a half after the establishment of the ICTY and the International Criminal Tribunal for Rwanda (ICTR), we know a great deal about the dynamics and outcomes of their battles for cooperation with the states of the former Yugoslavia and Rwanda. Much less is known about the ICC's ongoing efforts to obtain cooperation from the Sudanese government as well as from the three other African countries in which the Court has initiated formal investigations. The aim of this article is to identify and examine the dynamics of the battles over cooperation fought between the ICC and the Sudanese government. The foregoing analysis is of course incomplete, given the ICC's relatively recent intervention in Sudan and the developing nature of the case against President al-Bashir. Still, this account aims to highlight the ways in which the ICC and Sudan have and are likely to continue to wage the battle over Sudan's legal obligation to comply with international prosecutions by handing over suspects and otherwise assisting the pursuit of international justice.

\section{Khartoum's Strategic Defiance of the ICC}

The last day of March 2005 represented a watershed for the ICC when the Security Council authorized the ICC to open investigations in Darfur. ${ }^{7}$ Because Sudan has not ratified the Rome Statute which established the ICC, and is therefore considered a 
non-State Party, the Court would have had no authority to investigate atrocities on Sudanese soil unless it received a referral from the Security Council to do so. However, as will be discussed below in section IV, it was by no means certain that the Council would authorize ICC intervention in Darfur, given that the United States, China, and Russia-all permanent members of the Security Council and each with the power to veto the Darfur referral-are also non-State Parties.

Well before the start of the ICC's investigation of the Darfur atrocities, ${ }^{8}$ the Sudanese government had reason to fear that even cases brought against mid-level government officials and members of the government-supported Janjaweed militia could implicate senior leaders, including President al-Bashir himself. Yet, up until MorenoOcampo brought the first charges against two Sudanese suspects in early 2007, the relations between Khartoum and the ICC were at times cordial. ${ }^{9}$ While the al-Bashir government did not allow the Court to open up an office in Khartoum, ${ }^{10}$ it permitted ICC investigators to meet with government and judicial officials on five separate occasions, ${ }^{11}$ primarily to determine if Sudanese courts had the capacity and willingness to prosecute the cases under ICC investigation. Under the complementarity principle, the ICC can only prosecute cases that a state is either unable or genuinely unwilling to prosecute itself. If the ICC determines that a state is unable or unwilling to prosecute a case, it then becomes admissible for ICC prosecution. The government's bestcase scenario was to be seen to cooperate with Moreno-Ocampo's admissibility probe and then have the ICC conclude that domestic courts in Sudan should retain the authority to prosecute war crimes suspects sought by the chief prosecutor.

Khartoum's limited cooperation with Moreno-Ocampo came to an end following the chief prosecutor's February 2007 announcement designating two Sudanese suspects for ICC prosecution. ${ }^{12}$ The prospects for state cooperation grew even dimmer a few months later when the ICC pre-trial chamber issued arrest warrants for the two suspects-Ahmad Harun, Sudan's minister of humanitarian affairs, and Ali Kushayb, a leader of the pro-government Janjaweed militia. ${ }^{13}$ Harun, the former interior minister, and Kushayb face fifty-one counts of crimes against humanity and war crimes relating to atrocities in 2003-2004. ${ }^{14}$ From early 2007, the government has been largely hostile toward the ICC. This antagonism has only intensified in the wake of MorenoOcampo's bid to prosecute President al-Bashir. In response to Sudan's defiance, the once conciliatory Moreno-Ocampo has become increasingly critical of the government and of Security Council inaction.

Well before Moreno-Ocampo sought an arrest warrant for al-Bashir in mid-2008, Sudan attempted to sideline the ICC and discourage international pressure to cooperate with the Court. In its campaign against the ICC, the government has honed a number of strategies used by other states, such as Serbia, Croatia, and Rwanda, whose nationals have been investigated and targeted for prosecution by the ICTY and ICTR. First, the al-Bashir government has argued that the ICC prosecutor has no legal right to prosecute Sudanese citizens and that the prerogative belongs exclusively to the Sudanese courts. To bolster its case, the government argues that it has not ratified the Rome Statute of the ICC nor consented to the obligations binding on State Parties. However, a Security Council referral to the ICC obliges a non-State Party, such as Sudan, to fully cooperate with the Court. By the terms of the UN Charter, a Security Council resolution adopted under Chapter VII of the Charter is binding on Sudan as a UN member state.

Sudan has also waged an intensive lobbying campaign to discredit the Court and its claims of impartiality. That the ICC has been imposed on Sudan against its will, just as the ICTY was created without Serbia's consent, has been used by Khartoum 
as evidence that the ICC is a political weapon controlled by the powerful states of the Security Council. Here, the government has accused the ICC of executing "a political agenda of countries targeting Sudan" 15 and pursuing a Western-instigated "conspiracy" against the government. ${ }^{16}$ The government has sought to portray the ICC as "a tool for the exercise of the culture of superiority" of Western states to punish weak states in Africa and elsewhere in the developing world. ${ }^{17}$ Key to the government's bid for impunity is its argument of "double standards," 18 specifically, that more powerful countries such as the United States are effectively immune from ICC scrutiny for crimes that their military may have committed overseas. ${ }^{19}$ Yet, at least in Darfur, the ICC's pursuit of prosecutions is not one-sided. Moreno-Ocampo has also targeted Darfuri rebels implicated in war crimes. Toward this end, he is seeking to prosecute three Darfuri rebels for the September 2007 killing of twelve African Union peacekeepers in Darfur. In May 2009, one rebel commander, Bahr Idriss Abu Garda, voluntarily appeared at the ICC for an initial hearing pursuant to a Court summons. ${ }^{20}$ The ICC's targeting of Darfuri rebels has so far done little to soften Khartoum's defiance. Indeed, there is the strong likelihood that for the foreseeable future only rebels and not Sudanese officials will face justice in The Hague.

The Sudanese government has taken the argument of Western bias one step further by launching a pan-African appeal for solidarity to thwart the ICC and its bid to prosecute President al-Bashir. It has portrayed the ICC as a neo-colonial institution bent on punishing not only Sudan but Africa as a whole. Khartoum has also sought and received public backing from Arab states by casting the ICC as an enemy of the Arab world. It is a pillar of Sudan's claim that the ICC is an anti-African court because it has so far only opened formal investigations (also referred to as country situations) on the African continent. This claim of bias ignores the significant ways in which some African states have engaged the ICC and sought international prosecutions. Indeed, three of the ICC's four situations (Uganda, Democratic Republic of Congo, and the Central African Republic) ${ }^{21}$ were initiated by state referrals to the Court. The allegations of the ICC's purported anti-African bias deserve deeper analysis than can be afforded in this article. Suffice it to say here that the question of how the chief prosecutor selects country situations and particular war crimes cases has been the subject of increasing scrutiny even among ICC advocates. ${ }^{22}$ Even as ICC officials refute the allegations of anti-African bias they are particularly troubling to the Court. "It is a very harmful debate for us ... and it is harmful to perceptions" of the Court, lamented a high-ranking ICC official in a December 2008 interview. $^{23}$

Sudan's strategy has not yet derailed the chief prosecutor's case against al-Bashir. As of mid-July 2009, the Security Council has not invoked Article 16 of the Rome Statute to suspend the al-Bashir case. And the near term prospects for such a suspension seem low, according to ICC observers and diplomats interviewed in mid-2009. ${ }^{24}$ Nevertheless, Sudan's anti-ICC campaign, which has been heavily backed by Libya (whose leader, Muammar el-Qaddafi, has held the chair of the African Union since early 2009) has borne fruit by rallying African and Arab states to publicly oppose the Court's pursuit of President al-Bashir. This opposition has so far culminated in an African Union statement, adopted in early July 2009 at an AU summit in Libya, calling on members not to cooperate in efforts to arrest al-Bashir and turn him over to the ICC. ${ }^{25}$ The AU sought to justify its action at the summit by pointing to the Security Council's failure to heed the call from African states to suspend the al-Bashir case. ${ }^{26}$ A campaign, backed by Sudan and Libya, to press African State Parties to the Rome Statute to withdraw from the ICC has to date not succeeded. ${ }^{27}$ However, the potential for this scenario remains troubling for ICC supporters. ${ }^{28}$ 
In the immediate aftermath of Moreno-Ocampo's mid-July 2008 request for an arrest warrant for al-Bashir, the African Union and the Arab League came out in opposition to the chief prosecutor's bid to prosecute the Sudanese president and called for the Security Council to suspend the case. ${ }^{29}$ The Arab League and the African Union again called for Security Council intervention after the ICC pre-trial chamber issued a warrant for al-Bashir's arrest in March 2009. The Arab League decision garnered significant international media attention, in part because it occurred at a summit meeting in Qatar in which al-Bashir attended and was warmly embraced by fellow Arab leaders. ${ }^{30}$ In an apparent attempt to flout the ICC arrest warrant and call attention to his considerable regional support, al-Bashir also traveled to Eritrea, Ethiopia, Libya, Egypt, and Saudi Arabia in March and April. Along with Qatar, these states have not ratified the Rome Statute and therefore do not have a legal obligation to arrest al-Bashir. In this respect, the ICC is at a significant disadvantage relative to the ICTY and ICTR insofar as all UN member states have a legal obligation to cooperate with these two UN tribunals. The Arab League's vocal support for al-Bashir is not surprising because of the lack of pre-existing support for the ICC among Arab States. Only three Arab League states (Jordan, Djibouti, and the Comoros Islands) have ratified the Rome Statute. However, the strong backing Sudan has received from the African Union has come as a particular disappointment to ICC supporters because thirty African countries are State Parties to the Rome Statute. ${ }^{31}$

The disappointment of ICC advocates has been sharpened in the wake of the AU's July 2009 statement in which African State Parties appeared to disavow their legal obligation to arrest al-Bashir if he should travel to their countries. The AU's statement, which poses a significant challenge to the authority of the ICC, has triggered strong criticism from human rights activists. "This resolution, the result of unprecedented bullying by Libya, puts the AU on the side of a dictator accused of mass murder rather than on the side of his victims," said Reed Brody of Human Rights Watch. ${ }^{32}$

Meanwhile, Sudanese officials have trumpeted the AU statement as a virtual invitation for al-Bashir to travel freely to African states that have ratified the Rome Statute and a sign of African unity against the ICC. ${ }^{33}$ However, the actual level of popular opposition in Africa to the al-Bashir case and the ICC more generally is far from clear. Moreover, not all African states that attended the Libya summit appear to have strongly backed the AU statement. ${ }^{34}$ However, in the days following the summit, Botswana appeared to be the only African state to publicly condemn the AU statement. Botswana's vice president, Mompati Merafhe, criticized Libya for not allowing adequate debate on the matter and called on African leaders not to "try to undermine the work of the ICC simply because one head of state ... has been indicted by the Court." 35

An important element in Sudan's campaign against the ICC is to heighten world fears that support for the Court will undermine the elusive quest for a negotiated peace in Darfur as well as jeopardize the tenuous 2005 Comprehensive Peace Agreement that brought an end to Sudan's devastating north-south civil war. The government's apparent aim is to shift international scrutiny from its role in the Darfur atrocities to the ICC's alleged interference in a possible peace settlement. As far back as the Security Council meeting of 31 March 2005, Khartoum warned that the ICC would subvert the peace process. ${ }^{36}$ Subsequently, the government called MorenoOcampo "enemy number one of peace in Darfur." ${ }^{37}$ In the aftermath of the chief prosecutor's request for an al-Bashir arrest warrant in July 2008, government officials, including al-Bashir himself, intensified this line of attack, going so far as to threaten retaliation if the ICC pre-trial chamber was to issue a warrant for the president's 
arrest. Beyond that, Sudanese officials issued thinly veiled threats against the vulnerable, undermanned international peacekeeping force in Darfur. ${ }^{38}$ The threats of bloodshed have hardly demonstrated Sudan's peaceful motives. The recent governor of south Darfur, for example, warned that if the al-Bashir case moved forward there would be "more genocide such as has never before been seen by anyone." 39

On the one hand, the government has denied a role in atrocities, as when President al-Bashir in October 2008 dismissed allegations of mass rapes of Darfuri women as fabrications. ${ }^{40}$ But on the other hand, the government has at times strategically acknowledged its hand in the violence, apparently to signal to the ICC and the world that its threats for yet more violence are deadly serious.

Khartoum has sought to blame any increase in violence and danger to Darfuris on Moreno-Ocampo's misguided pursuit of prosecutions. However, in the immediate aftermath of the March 2009 arrest warrant, al-Bashir retaliated by targeting the international humanitarian presence in Darfur that provided a lifeline to millions of Darfuris. Al-Bashir expelled thirteen international and three domestic aid organizations that together had been responsible for providing crucial humanitarian relief to more than four million vulnerable civilians in Darfur. ${ }^{41}$ The expulsions sparked dire warnings over the fate of the vulnerable Darfuris. Al-Bashir sought to justify the expulsions by accusing these humanitarian organizations of spying on behalf of the ICC. ${ }^{42}$

For Chief Prosecutor Moreno-Ocampo, al-Bashir's actions have confirmed his criminal intent, making his arrest even more urgent. Still, the unfolding crisis triggered by the expulsions have, at least in the short term, appeared to soften international pressure for the president's arrest as Western diplomats have focused on obtaining Khartoum's cooperation to allow other humanitarian aid organizations to replace the expelled groups. In this respect, the United States appears to have taken a conciliatory approach toward Sudan, apparently aimed at ameliorating the Darfur crisis and preventing the collapse of the Comprehensive Peace Agreement. ${ }^{43}$

The Sudanese government's repudiation of the ICC is both strategic and deeply felt, according to Western diplomats. "If there is one thing that can get them out of their chair, it's the ICC issue. It's really, really upsetting for them," remarked a European diplomat who has met with Sudanese officials in Khartoum. ${ }^{44}$ Beyond declaring its intent never to hand over indicted suspects, the government has taken steps to marginalize the ICC and prevent international intervention on behalf of the Court. Well before the issuance of the al-Bashir arrest warrant, the government used incendiary rhetoric in an apparent attempt to demonstrate that its non-compliance is non-negotiable. In March 2007, for instance, Interior Minister Al-Zubayr Bashir Taha promised to "cut the throat of any international official ... who tries to jail a Sudanese official in order to present him to the international justice." 45 Then in April 2008, Sudan's ambassador to the UN, Abdel-Mohmood Mohamad, called for the arrest of Moreno-Ocampo, accusing him of "jeopardizing the political settlement in Darfur." 46 In early June 2008, President al-Bashir reportedly told members of a Security Council delegation visiting Khartoum that he would cooperate with the Court "over his dead body." 47 The day after the ICC pre-trial chamber issued a warrant for his arrest, al-Bashir told a pro-government rally in Khartoum that Sudan is "ready for any battle" against the "new colonization" represented by the ICC. ${ }^{48}$ Taken together, these statements may be interpreted as a government bid both to signal the futility of international pressure and the political price the international community will have to pay for exerting such pressure.

Yet even as the chief prosecutor's request for an arrest warrant for al-Bashir provoked hostile reactions in Khartoum, including government-sponsored protests 
against the ICC, ${ }^{49}$ government officials in the second half of 2008 offered slender olive branches to the international community, but not to the ICC. The Sudanese government promised that the situation in Darfur would improve, although it only offered minor concessions toward this end ${ }^{50}$ Behind what Human Rights Watch called a "dual strategy of threats of further violence and promises of progress on the ground"51 was a drive to convince the Security Council to invoke Article 16 and suspend the al-Bashir case. However, by the end of 2008, the government's strategy had not persuaded the Security Council.

In its quest for an Article 16 suspension of the al-Bashir case in the second half of 2008, the government argued, as it had when Moreno-Ocampo first opened his investigation in 2005, that under the Rome Statute's complementarity principle its courts are capable of handling Darfur-related prosecutions. Sudan's allies in Africa and the Arab world sought to broker a compromise to the crisis over the impending ICC warrant by encouraging Khartoum to develop a plan for credible domestic war crimes prosecutions. $^{52}$ Toward that end, the government announced the appointment of a special prosecutor for Darfur. ${ }^{53}$ And in October 2008, the Sudanese government announced that it had arrested Ali Kushayb. ${ }^{54}$ (Government authorities had previously arrested Kushayb, but then released him in 2007.) But by the end of 2008 scant progress had been made toward domestic prosecutions and there was little sign that the government planned to prosecute Kushayb or Ahmad Harun, the other Sudanese suspect facing an ICC arrest warrant. ${ }^{55}$ Chief Prosecutor Moreno-Ocampo was emphatic in his criticism of how little Sudan had done in the realm of domestic war crimes prosecutions, telling the Security Council in December 2008 that "in spite of recent announcements and appointments, nothing-nothing-has been done." 56 In another attempt to sideline the ICC, a deal was reportedly explored whereby the Sudanese government would send Harun and or Kushayb for trial in The Hague in exchange for an Article 16 suspension of the al-Bashir case. In August 2008, the idea surfaced with potential support from France and Britain, ostensibly the ICC's two strongest backers among the Security Council's five permanent members. But in October, momentum for such a deal died after Khartoum stood by its long-held refusal to hand over the two suspects or to make significant concessions in regard to ameliorating the conflict in Darfur. ${ }^{57}$

In the aftermath of the chief prosecutor's application of an arrest warrant for al-Bashir, some Western diplomats and many ICC supporters have scoffed at the suggestion that the Court's work would jeopardize a resolution to the Darfur crisis given the moribund state of the peace negotiations. "Show me the peace process, please," one high-level ICC official said in a December 2008 interview. ${ }^{58}$ Still, the prospect that the Court's pre-trial chamber would issue an arrest warrant raised fears in many capitals that the Darfur crisis would grow worse at the hands of an embattled leader. Many diplomats also feared that casting al-Bashir as a pariah would, for as long as he remains in power, make it difficult for the international community to directly engage him to find a resolution to the Darfur conflict or ensure the success of the fragile Comprehensive Peace Agreement. To be sure, the indictment of a sitting head of state is bound to be highly controversial, even if it is enabled by a Security Council referral. The central concern is that a cornered al-Bashir would have no incentive to bring the war in Darfur to an end and perhaps every reason to prolong it. Yet, by holding the keys to the Darfur conflict-either by unleashing more violence or by working toward its resolution-al-Bashir's behavior may yet be restrained in the hopes of obtaining the golden prize of an Article 16 suspension. 
Even before the emergence of the al-Bashir case, some Sudan experts expressed concern that the ICC's expected charges against senior officials in Khartoum could provoke further instability in Darfur, trigger violence in the fragile oil-rich Abyei region leading to a resumption of the north-south war, and prompt government retaliation against humanitarian workers and peacekeepers. For instance, former US Special Envoy to Sudan Andrew S. Natsios warned of a doomsday scenario in which new ICC indictments "will drive the country closer to dissolution." 59 This, Natsios feared, could destabilize neighboring countries, disrupt Sudan's oil exports, and force an increase in world prices. ${ }^{60}$ The concern that the pursuit of justice could damage the prospects of an already elusive peace in Darfur have been sharpened in the wake of the chief prosecutor's bid to bring al-Bashir to trial in The Hague and the issuance of the warrant for the Sudanese president. Yet other experts, including representatives of prominent international human rights organizations, view the move to prosecute al-Bashir as a potential catalyst to confronting and ultimately ending the atrocities in Darfur.

Even prior to the chief prosecutor's targeting of al-Bashir, the Sudanese government argued that the ICC interfered with efforts to bring the Darfur conflict to an end. Specifically, Khartoum warned that the arrest warrants for Harun and Kushayb could disrupt the bid for the deployment of an expanded African Union-UN peacekeeping force in Darfur. President al-Bashir argued that his previous refusal to allow UN peacekeepers into Darfur was based on his fear that the ICC would take advantage of evidence possibly collected by the peacekeepers. ${ }^{61}$ This argument has been refuted by some analysts who contend that Sudan disingenuously blamed the Court for the government's long-running resistance to a robust peacekeeping force. These analysts point to the fact that Sudan's foot-dragging on allowing an effective peacekeeping force had begun a year and a half before the Security Council's 2005 referral of the Darfur case to the ICC. Moreover, their contention that the government's announced fear that the peacekeeping force would be used on the ICC's behalf is a distortion of the force's limited mandate. ${ }^{62}$

While the ICTY and ICTR have often been stymied by non-cooperation, the states of the former Yugoslavia and Rwanda have frequently sought to portray themselves as cooperative in order to avoid international condemnation. When these states have been accused of non-cooperation, they have often advanced "good faith" reasons for their behavior, such as a lack of state capacity to locate and arrest fugitives. ${ }^{63}$ But Sudan has frequently been unambiguous in its determination to withhold cooperation. Sudan's open defiance may serve both as a way to further undermine the ICC and as an expression of its confidence that the international community will not punish the government for its non-compliance.

Khartoum has also taken a number of provocative actions to emphasize its opposition to the ICC. The government has retained Harun in his position as minister of humanitarian affairs, where he has responsibility over vulnerable refugees in camps in Darfur. And Khartoum has actually given him the responsibility of investigating human rights abuses in Darfur and serving as the government's liaison with the AU-UN peacekeeping force. "It's a real slap to the ICC and the arrest warrants," remarked a Western diplomat based in The Hague. ${ }^{64}$ In the fall of 2007, the government announced it released Kushayb, who had been arrested by Sudanese authorities on charges unrelated to the ICC case against him. Then in January 2008, the government promoted Musa Hilal-a notorious Janjaweed leader implicated in atrocities and rumored to be a potential target of the ICC chief prosecutor-as a special advisor 
to President al-Bashir. Court advocates lament that by failing to formally condemn Khartoum's defiance, the international community has given Sudan more political space to thwart the ICC's calls for compliance. ${ }^{65}$

Still, the crisis brought on by the prosecutor's request for an al-Bashir arrest warrant has, as discussed earlier, prodded some Sudanese officials to signal a show of willingness to change their behavior in Darfur. Time will tell whether this takes the form of substantive concessions and whether this will persuade the Security Council to exercise its prerogative to suspend the pending ICC case against President alBashir.

\section{The Changing Approach of the ICC Chief Prosecutor}

The decision of Chief Prosecutor Moreno-Ocampo to target a sitting head of state and to seek charges of genocide, crimes against humanity, and war crimes have brought the ICC to the center of world attention. The genocide charge in particular has sparked controversy and renewed the contentious debate over whether the Darfur atrocities deserve to be categorized as "the crime of crimes." Key flashpoints in this controversy have occurred with the release of the UN-authorized International Commission of Inquiry report in 2005, which did not find that genocide had taken place in Darfur, ${ }^{66}$ and the United States government's 2004 determination that genocide had occurred. ${ }^{67}$ The genocide debate has received extensive treatment in the academic literature. $^{68}$

The chief prosecutor's high-profile campaign for al-Bashir's arrest, together with his pursuit of Ahmad Harun and Ali Kushayb, have cast him as a confrontational prosecutor not unlike his former ICTY counterpart, Carla Del Ponte. However, MorenoOcampo's adversarial approach particularly applies to Sudan, the only country in which the Security Council has asked the prosecutor to investigate violations of international humanitarian law. ${ }^{69}$ By virtue of this Security Council referral, MorenoOcampo, as with his counterparts at the ICTY and ICTR, possesses the ostensible backing of the highest UN body to target senior political and military officials. This stands in decisive contrast to the ICC's involvement in Uganda, the Democratic Republic of Congo, and the Central African Republic, where the Security Council has played no role in initiating the Court's work. With the Security Council's referral, the prosecutor is given a level of authority he lacks in the three other country situations in which he is currently pursuing war crimes prosecutions. Moreover, when it comes to the Darfur situation, the prosecutor has access to the high-profile forum of the Security Council chambers in New York where he issues biannual progress reports and can thus garner significant international media attention and political leverage in his quest for cooperation.

For the chief prosecutors at the UN ad hoc tribunals, and particularly at the ICTY, confrontation has often been critical to securing cooperation. Since the Security Council had given them the task of holding scores of trials within a finite period of time and equipped them with a legal mandate to demand full and immediate cooperation, the ICTY chief prosecutors often had reason to take a hard line with non-compliant states. But as seen in key provisions of the Rome Statute, the founders of the ICC envisioned a more consensual relationship between Court and states. Whereas the Security Council established the ad hoc ICTY and ICTR, the ICC was created by a multilateral treaty to which states have to consent in order to join. And whereas the ICTY and ICTR have enjoyed primacy vis-à-vis states and the legal authority to usurp domestic judiciaries, the ICC is more deferential because it is only authorized to prosecute when a state is either unwilling or unable to do so itself. The spirit if not the letter of 
the Rome Statute also seemed to call on the ICC chief prosecutor to pursue a more harmonious relationship with states.

Adopting a conciliatory approach in his external relations also appeared to be a prudent political strategy for Chief Prosecutor Moreno-Ocampo to increase the prospects that powerful states opposed to the Court would reconsider their position. A crusading chief prosecutor could quickly alienate State Parties and provoke the wrath of powerful non-State Parties - the United States in particular-that the Court hoped to count on for vital assistance. Accordingly, Moreno-Ocampo signaled his deference to state sovereignty by declining to initiate investigations himself, although the proprio motu powers in Article 15 of the Rome Statute allows him to do so. Article 15 had been a hard fought victory at the 1998 Rome Conference and is viewed by advocates as crucial to ensuring the prosecutor's independence. ${ }^{70}$ However, as the first chief prosecutor of a fledgling institution that relies on state support and seeks to increase the number of State Parties, Moreno-Ocampo initially seemed more concerned with signaling his accountability to states than in maintaining his independence from them. ${ }^{71}$ Still, under pressure from supporters and skeptics alike to demonstrate the Court's relevance, Moreno-Ocampo could not wait indefinitely for State Parties to come to him with referrals of new country situations.

Laboring under these constraints, Moreno-Ocampo adopted a policy of actively encouraging referrals from State Parties. ${ }^{72}$ In effect, the prosecutor asked these states to ask him to open investigations. This is apparently the route by which the Office of the Prosecutor came to investigate atrocities in Uganda ${ }^{73}$ and Congo. ${ }^{74}$ The strategy of self-referrals allowed Moreno-Ocampo to avoid the image of an adversarial prosecutor and helped secure the state's cooperation in the ICC's investigations, at least as long as he did not actually target the Ugandan and Congolese governments' role in atrocities. That these states invited the ICC into their countries could also be later used by Moreno-Ocampo and other Court officials to deflect the accusations that the ICC is an anti-African court imposing justice on Africa. ${ }^{75}$ However, a central concern of critics, including some prominent legal scholars, is that Moreno-Ocampo's reliance on state referrals can lead to a quid pro quo that insulates state officials from ICC prosecution. $^{76}$

The chief prosecutor's strategic conciliation vis-à-vis Uganda and Congo initially seemed a harbinger of a timid approach toward Sudan. To the dismay of some international human rights activists, Chief Prosecutor Moreno-Ocampo at first avoided confronting the al-Bashir regime for its insufficient cooperation. ${ }^{77}$ These activists asserted that he did little to build the necessary international pressure that might have bolstered the prospects of cooperation, but instead advanced an acquiescent image of the ICC and the Office of the Prosecutor. ${ }^{78}$ Moreno-Ocampo has not been alone in employing conciliation in a bid for cooperation. The chief prosecutor's counterparts at the ICTY and ICTR have at times also believed that a softer approach offers the best opportunity to persuade recalcitrant states to provide some cooperation. ${ }^{79}$ "He had a strategy ... [that] if he played nice with the regime he would have much more chance of getting a degree of cooperation," said a prominent NGO official who has watched Moreno-Ocampo since he began his tenure as chief prosecutor. "It is a legitimate kind of thing for him to think about, but I think it was a complete misreading of the way in which his investigation was perceived [by Khartoum] ... This was a threat to the regime." 80 Moreno-Ocampo came under fire from human rights activists for two apparent overtures to Sudan. First, in his early reports to the Security Council in 2005 and 2006, he provided favorable assessments of the government's limited cooperation. Next came his request to the ICC's pre-trial chamber in early 2007 for 
a summons rather than arrest warrants for Harun and Kushayb. The request for a summons-which is usually reserved when there is reason to anticipate voluntary surrender-was apparently made to lower the domestic political fallout to President al-Bashir of relinquishing the suspects, since it might have allayed the perception of government acquiescence. ${ }^{81}$ Nevertheless, the government spurned Moreno-Ocampo's overtures. The ICC's pre-trial chamber did as well, deciding to issue warrants for Harun's and Kushayb's arrests after citing Sudan's declarations of resistance. ${ }^{82}$

Some observers maintain there was a sound basis for a conciliatory approach, at least during the investigation phase when Khartoum was not unequivocally hostile to the ICC. ${ }^{83}$ Alex de Waal, a prominent Sudan expert, believes that because Harun and Kushayb were not from the highest levels of government, Khartoum could have sent them to The Hague without significant domestic fallout. ${ }^{84}$ (In the wake of MorenoOcampo's bid to prosecute al-Bashir, de Waal has grown sharply critical of the prosecutor's "overreach" 85 as well as his overall performance as chief prosecutor). ${ }^{86}$ Moreno-Ocampo has also said that the government indicated some interest in surrendering Harun after the arrest warrants for him was issued. "Khartoum was discussing internally the possibility to remove Harun from the government; they were asking us questions about the consequences of surrender," Moreno-Ocampo said. ${ }^{87}$ It was at this point, he asserts, that international pressure on Khartoum could have played an important role in the arrest and transfer of Harun and Kushayb to The Hague. But the UN and European actors declined to make the arrests a priority. "The international community preferred to deny the facts and the need to enforce the judges' decision," Moreno-Ocampo said in a stinging rebuke of UN and European acquiescence. ${ }^{89}$

Moreno-Ocampo's decision to adopt a confrontational stance toward Khartoum, which became evident in mid-2007, likely stemmed from a realization that his previous approach was not yielding results. ${ }^{90}$ The nature of his relationship with Sudan had fundamentally changed with the issuance of the first arrest warrants of Sudanese suspects that implicated the government in a campaign of ethnic cleansing in Darfur. In the eyes of the al-Bashir government, the warrants for Harun and Kushayb confirmed its long-held fear that the ICC would target the regime itself. Still, for Moreno-Ocampo to maintain a conciliatory stance by not criticizing Sudan's blatant non-compliance would have sorely undercut his leverage and hopes of building international pressure for the arrests of Harun and Kushayb.

Since the issuance of the arrest warrants for Harun and Kushayb, MorenoOcampo has taken an increasingly adversarial stance toward the Khartoum government. Moreno-Ocampo's confrontational approach reached its apex with his request for an arrest warrant for al-Bashir and the prosecutor's subsequent campaign, in the aftermath of the March 2009 warrant, for the president's arrest. Well before the al-Bashir case, the chief prosecutor demonstrated more resolve to obtain arrests, as seen in his audacious plan, in conjunction with some third-party states, to divert an airplane that Harun was expected to be on en route to the haj pilgrimage in Saudi Arabia in December 2007. The plan was unsuccessful because Harun got off the plane after being tipped off. Still, Moreno-Ocampo has used the disclosure of the arrest attempt to project his determination and the ICC's global reach. "As soon as Harun leaves Sudan he will be arrested," Moreno-Ocampo said in June 2008. "He is a fugitive. Inside Sudan he could have freedom. Outside Sudan he will be in jail."91 The Khartoum government responded to the news by denouncing the prosecutor's action as "piracy," 92 calling for his ouster, and announcing that it had filed domestic terrorism charges against him. ${ }^{93}$ 
A key component of Moreno-Ocampo's strategy for international support has been to argue that the arrests of all three suspects, but particularly al-Bashir and Harun, are imperative to stopping the violence against Darfuris. Moreno-Ocampo contends that al-Bashir, as president, and Harun, as minister of humanitarian affairs, are responsible for ongoing attacks against civilians in Darfur. Even as the magnitude of atrocities in Darfur has receded from the height of the conflict in 2003-2004, there is still violence that the prosecutor maintains poses a threat to the survival of members of the Fur, Masalit, and Zaghawa tribes in Darfur. In his December 2007 address to the Security Council, the prosecutor sought to implicate Harun in ongoing abuses against Darfuris in refugee camps, maintaining that the displaced "are left with no hope for the present and no prospect for the future."94 Moreno-Ocampo pursued a similar line of attack in his December 2008 speech to the Security Council, his first address to the Council following his application for the al-Bashir arrest warrant. He reported on the continuation of rapes, military attacks against civilians leading to deaths and wide-scale displacement, and government hindering of humanitarian aid. "Genocide continues," Moreno-Ocampo alleged in his address to the Security Council. ${ }^{95}$ Then in his June 2009 address to the Council he charged that al-Bashir's expulsion from Darfur of more than a dozen humanitarian aid organizations amounted to a policy of extermination. ${ }^{96}$ Moreno-Ocampo also has highlighted the emptiness of al-Bashir's promise to his citizens, which he made in the fall of 2008 , to provide "justice to the oppressed." 97 Pointing to the regime's effort to cover up crimes by arresting and torturing human rights activists who have given information to the ICC, the prosecutor sardonically told the Security Council: "This is the 'justice to the oppressed' that President Al-Bashir is talking about." 98 In sum, in his recent speeches to the Security Council and other public statements, the prosecutor has tried to deflect charges that the ICC undermines peace by framing the pursuit of justice as "the only realist solution" 99 to preventing the suspects from endangering more civilians.

Without naming art. 16, Moreno-Ocampo, in his December 2008 speech, also countered the Sudanese government's efforts to obtain a suspension of the al-Bashir case. By casting the regime's attempts at an Article 16 resolution as a means to win impunity for its crimes, the prosecutor sought to pre-emptively shame the Security Council from taking this course of action. "President Al-Bashir is trying to convince organizations and the Security Council that they have to protect him," Moreno-Ocampo told the Council. "The international community cannot be part of any cover-up of genocide or crimes against humanity." 100 Even as Moreno-Ocampo's speeches attest to his increased confrontation with the Sudanese government, they also have underscored his growing impatience with the Security Council for its timid approach toward Khartoum. ${ }^{101}$ Beyond that, the prosecutor has argued that Sudan's defiance of the ICC is defiance of the Security Council itself. ${ }^{102}$

\section{The ICC in Sudan: Security Council Authorization and Ambivalence}

Following their March 2005 referral of the Darfur situation to the ICC, Security Council members extolled the virtues of the Court and its potential to advance the pursuit of peace. The French ambassador to the UN, Jean-Marc de la Sablière, hailed Security Council Resolution 1593 as evidence that the "Council will remain vigilant to ensure that there is no impunity." 103 And UN Secretary-General Kofi Annan called the ICC "an appropriate mechanism to lift the veil of impunity that has allowed human rights crimes in Darfur to continue unchecked." ${ }^{104}$ Yet, as the discussion herein shows, the Security Council grew ambivalent over whether prosecutions of Sudanese officials 
would aid the quest for a durable solution to the Darfur crisis. The Council's ambivalence has become particularly apparent in regard to the ICC's bid to prosecute President al-Bashir. As a result, the Security Council's referral of the Darfur situation has not materialized into a sustained commitment to press Sudan to cooperate with the ICC.

Since its 2005 referral, the Security Council has taken no punitive steps against Sudan despite its blatant non-cooperation and public declarations that it will never cooperate with the Court. With the exception of a June 2008 Security Council statement calling on Khartoum to assist the ICC, the Council as a collective has been silent about Sudan's obligation to cooperate. ${ }^{105}$ Analysis of the numerous resolutions and statements the Security Council has adopted on Sudan, prior to the June 2008 statement, finds no formal criticism or explicit acknowledgement of Sudan's non-compliance. Beyond that, Security Council resolutions and statements on Sudan prior to June 2008 included no mention of the ICC and on only two occasions made reference to the Council's referral to the Court. When the Council did list the international obligations Sudan must fulfill—such as supporting the peace process, halting attacks on civilians and peacekeepers, and expediting humanitarian relief-cooperation with the ICC was noticeably omitted. ${ }^{106}$ The Council mentioned the need for justice in some of its resolutions and statements on Sudan. But it either did so in vague terms, ${ }^{107}$ did not specify the ICC's role in undertaking prosecutions, or indicated, as it did in a July 2007 resolution, that justice is the responsibility of Sudan's domestic courts. ${ }^{108}$ In so bypassing the ICC, the Council (prior to its June 2008 statement calling for Sudan's cooperation) backed away from its own commitment to the ICC. Although hardly noticed by the international media and the outside world, this eliding of the ICC appeared to reduce the pressure that the government would have otherwise faced from the Council. ICC advocates have expressed concern that the Council's failure to demand Sudanese cooperation threatens to magnify the Court's impotence. ${ }^{109}$

The Security Council's reluctance to confront Sudan for its non-cooperation with the ICC bears a striking parallel to the Council's reticence to take action against Serbia in the 1990s for failing to cooperate with the ICTY. In both instances, the prospect of war crimes prosecutions provided the Council with leverage to curtail state violence insofar as the tribunals served to warn state leaders that they might one day face prosecution. The Council's establishment of the ICTY and the Council's referral of the Darfur situation to the ICC have also served other political functions such as insulating the UN from its failure to take decisive action to halt mass killings by, instead, taking the moral high ground of seeking international justice. In this respect, both the creation of the ICTY and the Darfur referral can partially be seen as a way to distract attention from the UN's failure to end the violence in the former Yugoslavia and Darfur.

The Security Council's reticence to press Sudan to cooperate with the ICC goes beyond its hope that the government will agree to a negotiated peace settlement in Darfur. It has also looked to Khartoum to fulfill its promise to allow the full deployment of an expanded 26,000-strong joint African Union-UN peacekeeping force in Darfur. (By early March 2009, approximately 15,000 international peacekeepers and other members of the AU-UN force had been deployed in Darfur. ${ }^{110}$ ) Moreover, the international community has continued to rely on the government to permit the unfettered delivery of humanitarian relief to vulnerable civilians in Darfur who have been internally displaced by the violence. This dependence on Sudan has, at times, led even strong ICC supporters such as the European Union to avoid applying sustained pressure on Sudan to cooperate with the Court. As a senior EU diplomat with first-hand 
knowledge of Sudan explained in a May 2008 interview, the ICC fits in the diplomatic landscape "like a stone in a shoe." 111 Said the EU diplomat: "It would require robust pressure on the government to [hand over suspects] to the ICC, robust pressure we're not inclined to put because of the need to engage" on several agendas. ${ }^{112}$ In sum, obtaining Khartoum's cooperation in the quest for peace, peacekeeping, and humanitarian relief-as well as its continued support for the endangered Comprehensive Peace Agreement that brought an end to the north-south civil war in early 2005has so far trumped the ICC's quest for the international community's political backing in the prosecution of war crimes.

Since mid-2007, Chief Prosecutor Moreno-Ocampo has issued increasingly strong calls for the Security Council to press Khartoum to comply with the ICC. Following the prosecutor's June 2007 speech to the Security Council, the UN body effectively shielded Sudan from public criticism by discussing his remarks in private sessions. ${ }^{113}$ The Council held a public discussion of the cooperation issue following the chief prosecutor's next report to the Council in December 2007. But, again, Moreno-Ocampo's criticism of Khartoum did not lead to punitive Council action or even the less serious step of issuing a Council statement rebuking Sudan for its non-compliance. Even the rejected Council statement under consideration was relatively mild, at most a reminder of Sudan's legal obligation to cooperate with the ICC. ${ }^{114}$ The most pro-ICC states on the Council-France, Britain, and Belgium-maintained that the Council should hold Sudan to its obligation to fully cooperate because the quest for justice complemented the pursuit of peace in Darfur while the anti-ICC states-China, Russia, and Qatar-countered that Council support for the ICC should be subordinated to the security question. The Russian delegation called for "a constructive dialogue" between Khartoum and the ICC. ${ }^{115}$ Yet, without Council pressure on Khartoum, the call for such dialogue would only benefit Sudan and foster the impression that the Court's work was vulnerable to political bargaining.

By spring 2008, the ICC chief prosecutor appeared to gain more international support for his uphill struggle for cooperation. Moreno-Ocampo's criticisms of Khartoum's non-compliance and international inaction, as well as a concerted NGO campaign that amplified the prosecutor's calls for cooperation, appeared to strengthen the prosecutor's hand, particularly in Europe. ${ }^{116}$ At the end of March 2008, the presidency of the European Union issued a statement expressing its "profound dismay"117 with Sudan's lack of cooperation, indicating that further non-compliance would lead to EU action against Khartoum.

At the Security Council, there was not enough political support for punitive measures against Sudan in 2008. Still, when Moreno-Ocampo addressed the Council in early June 2008, he received more backing than ever before, with a majority of members favoring a Council statement addressing Khartoum's non-compliance. In the prosecutor's speech to the Council, he called "the entire Darfur region a crime scene," implicated the "entire state apparatus" in atrocities, and excoriated Khartoum for a cover-up. ${ }^{118}$ Ten days after this no-holds barred speech, the Council approved a statement "urging" the government "to cooperate fully with the Court ... in order to put an end to impunity for the crimes committed in Darfur." 119 The prosecutor's accusations of Ahmad Harun's ongoing responsibility in attacks against victims in refugee camps may have prompted the Council to break its silence. Significantly, the United States which held the Council presidency that month also came out in favor of such a statement and by doing so indicated its strongest support of the ICC to date. ${ }^{120}$ In the ensuing months, the United States would increasingly play a supportive role for an institution it had only recently been determined to undermine. Washington's refusal 
to contemplate supporting an Article 16 suspension of the al-Bashir case even as France and Britain indicated openness to doing so highlighted the significant evolution in the United States' relationship with the ICC.

That Moreno-Ocampo sought and received a Security Council statement in June 2008 seemed designed to bolster his leverage with the Council ahead of his request for an al-Bashir arrest warrant a month later in July. ${ }^{121}$ Human Rights Watch hailed the Council's June statement, characterizing it as a criticism of Khartoum's noncompliance and as a sign of the UN's impatience with impunity in Darfur. ${ }^{122}$ Yet the Council statement lacked any explicit criticism of Khartoum's non-compliance. Moreover, the Council dropped the explicit reference in the draft statement demanding Sudan's compliance with the ICC arrest warrants. Libya, a non-permanent member of the Council, reportedly would not endorse the statement unless the reference to the warrants was replaced with the vague and less consequential call for an "end to impunity." ${ }^{123}$ For its part, the European Union issued a much stronger statement of its own. After Moreno-Ocampo addressed the EU foreign ministers on 16 June, the ministers issued a statement deploring the government's failure to cooperate and calling for the handover of Harun and Kushayb. ${ }^{124}$ Still, at their June meeting, EU leaders decided to hold off on imposing sanctions against Khartoum. For the rest of the year, European leaders backed away from their threat of taking concrete action against the Sudanese regime even as the now targeted President al-Bashir flouted his defiance of the ICC.

The lack of concerted Security Council action on the ICC issue is a product of the political interests and divisions among its five permanent members, particularly the United States, China, and Russia. Yet what is commonly overlooked is that the ICC's strongest backers on the Council, Britain and France, have also been ambivalent about strongly supporting the ICC's struggle with Sudan. Even as London, Paris, and other European capitals have been at the forefront of the effort to establish the ICC, their lack of forceful and sustained pressure on Khartoum has disappointed ICC officials and Court advocates. ${ }^{125}$ Still, the ICC's more fundamental problem has been with the United States, China, and Russia. All three states have not ratified the Rome Statute and have generally not been eager to embolden the ICC. However, the nature of their views toward the ICC and their role in Sudan have differed in key respects.

Despite its leadership role in establishing the contemporary ad hoc tribunals, the United States under the Bush administration vehemently opposed the ICC, which it accused of being unaccountable and a danger to American interests. Particularly in the early years of the Bush administration, this opposition translated into a diplomatic assault on the Court and a coercive campaign to press states to sign bilateral agreements with Washington promising not to send any American war crimes suspects to the ICC. ${ }^{126}$ Thus, the United States was initially loath to take any action that could legitimize the fledgling court. ${ }^{127}$ Toward that end, US officials made it clear in early 2005 that the US opposed the nascent plan for the Security Council to refer the Darfur situation to the ICC. ${ }^{128}$ Instead, the Bush administration floated a plan for an ad hoc tribunal for Sudan jointly run by the UN and the African Union. Washington's ad hoc tribunal plan did not gain political traction and was effectively criticized by other states, ICC supporters, and American Darfur activists as a costly and unnecessary alternative. ${ }^{129}$ In time, the threat of a US veto of the Security Council's proposed Darfur referral became untenable because of the likely political damage of blocking international prosecutions for atrocities the Bush administration had itself labeled genocide 
only a half a year earlier. ${ }^{130}$ Not wanting to publicly endorse the ICC, Washington decided to abstain on the vote to refer the Darfur situation to the ICC.

In time, Washington came to regard the ICC's work in Darfur in a favorable light, perhaps in no small part due to the high-profile status of the Darfur issue in the United States and the formidable pressure exerted by the American-based Save Darfur movement to stand against impunity in Sudan. ${ }^{131}$ Moreover, just as the ad hoc ICTY had been a useful tool for the United States and its allies to isolate the rogue leader of Serbia, there was no reason why the ICC, at least in the context of the Darfur situation, could not serve a similar purpose for the United States. Indeed, the Security Council referral could serve American interests because the Council's action had, in effect, deputized the global court to serve as an ad hoc tribunal for Darfur. Late in the Bush years, US officials reached out to the Court, indicating they would actually cooperate with the ICC in its Darfur investigations if so requested. ${ }^{132}$ Yet the strongest form of US support came in the second half of 2008 when the Bush administration announced its opposition to any Security Council attempt to invoke Article 16 to suspend the al-Bashir case. Even as France and Britain explored a possible deal to suspend the case, Washington, in sharp contrast to its earlier position on the ICC, claimed the moral high ground. "There is no compromise on the issue of justice," said Alejandro Wolff, the deputy US representative to the UN, in early August. ${ }^{133}$ Remarkably, in only the span of a few years, the United States has gone from being the ICC's arch-nemesis to its most reliable ally, at least when it perceived that providing backing for the Court in Darfur advanced American interests. Yet finding common cause with the ICC did not mean that the United States government, under Republican George W. Bush or Democrat Barack Obama, would fully embrace the Court by becoming a State Party to the Rome Statute.

American opposition to an Article 16 suspension, at least in the run-up to the pretrial chamber's decision on the al-Bashir arrest warrant, greatly diminished the prospects of such a suspension since an opposing vote of only one permanent Council member can block a suspension. Anticipating failure may have thus dissuaded China and Russia from mounting a vigorous public campaign. Such a campaign was not only likely to fail but also could incur a blow to their global standing by closely linking Beijing and Moscow in the effort to immunize President al-Bashir from prosecution.

As Sudan's most important political patron, China has reaped concrete benefits from its relationship with Khartoum, not least of which has been substantial crude oil imports_-Sudan is China's largest foreign supplier ${ }^{134}$ —and the extension of Chinese influence in a strategic part of Africa. Sudan, too, has enjoyed the benefits of its relationship with China, given Beijing's role as a major supplier of arms ${ }^{135}$ and China's significant investment in Sudanese industry. ${ }^{136}$ Beyond that, China's political backing during the Darfur crisis has proven indispensable for Sudan. China's support has helped to soften the blow of international condemnation and to avoid some punitive measures from the international community, such as a maritime blockade of its ports, ${ }^{137}$ which might have forced Khartoum to alter its policy in Darfur. Significantly, however, the political protection China has offered Sudan did not extend to a Chinese veto of the Security Council referral of the Darfur situation to the ICC.

China is no friend of the ICC. Since the Rome Conference of 1998, it has been strongly opposed to key provisions of the Court's Statute. Yet, when it came time to the vote on the Darfur referral, Chinese leaders preferred to avoid risking the condemnation that may have come from scuttling any possibility of international justice for Darfur. Instead, Beijing, like Washington, abstained. China "could not vote no since 
the crimes in question are unjustifiable," observed Jean-Pierre Cabestan, a French expert on China. "It often finds itself in this neutral position since it does not want to have the finger of blame pointed at it." 138

As the Darfur crisis has worn on, China has found itself increasingly subject to international censure, especially from human rights activists in the West, who have criticized Beijing for complicity in atrocities by enabling and arming the Khartoum regime. As international scrutiny of Chinese human rights practices at home and abroad intensified during the long run-up to the 2008 August Olympics in Beijing, China sought to enhance its international image by being seen to play a constructive, diplomatic role in Darfur. ${ }^{139}$ Thus, Chief Prosecutor Moreno-Ocampo's request for an arrest warrant for President al-Bashir, less than a month before the Olympics, came at a particularly sensitive time for the Chinese government. In this context, China risked a deep, self-inflicted wound if it had lead or strongly supported efforts to suspend the case against a potential genocide suspect.

To be sure, China did express opposition to Moreno-Ocampo's bid to prosecute al-Bashir, criticizing the move as "an inappropriate decision taken at an inappropriate time" 140 that could make it more difficult to resolve the Darfur crisis. Beyond that, an arrest warrant would obviously complicate Chinese diplomacy in Sudan. As Liu Guijin, China's envoy for Darfur, asked rhetorically, "How can you rely on a criminal suspect to be a responsible partner for the Darfur political process?"141

Not long after the chief prosecutor's mid-July 2008 request for an arrest warrant, China signaled support for "the reasonable request"142 of Sudan's African and Arab allies for an Article 16 resolution at the Security Council. Yet Beijing was careful not to go beyond these measured statements of support for Sudan and its African and Arab backers. However, as the global spotlight on China faded several months after the Olympics and the announcement of the ICC's pre-trial chamber's decision appeared imminent, Beijing in early January 2009 signaled stronger support for halting the al-Bashir case, arguing that an ICC indictment would lead to "disastrous" consequences for Darfur. ${ }^{143}$ Still, China indicated that it preferred to have one of the Security Council's three African members take the lead by introducing an Article 16 resolution.

For the most part, Russia has followed China's lead when it has come to the ICC and the al-Bashir question. However, in contrast to both China and the United States, Russia voted to refer the Darfur situation to the ICC. While Russia has supplied the Sudanese military with arms-including airplanes and helicopter gunships linked to Sudanese bombing attacks in Darfur ${ }^{144}$ _its relationship with Khartoum is not as close as China's. Still, like Beijing, Moscow has criticized Moreno-Ocampo's bid to prosecute al-Bashir, indicated support for the African and Arab campaign for a suspension of the case, and credited Sudan's role in working toward a diplomatic resolution of the Darfur conflict. ${ }^{145}$

\section{Conclusion}

In Sudan, the ICC faces a government as defiant as any that the other contemporary international war crimes tribunals have confronted. When it comes to the prosecution of members of their own national, political, or ethnic group, states employ a range of strategies to withhold cooperation and to limit the political cost of doing so. But with its statements of contempt and intimidation-and its expulsion of more than a dozen humanitarian aid groups from Darfur after the issuance of the arrest warrant for President al-Bashir-Khartoum has taken such defiance to a new level. 
In June 2008, the Security Council's statement calling for Sudanese compliance with the ICC appeared to demonstrate a new resolve to press the government and defend the integrity of the Council's authority. After more than a year of allowing Sudan's resistance to go unchallenged, the Council's statement indicated there may be a limit to its passivity. But then a month later in July, Chief Prosecutor MorenoOcampo's request for an arrest warrant for President al-Bashir seemed to weaken the Council's new backing of the ICC. The question then shifted from whether the Security Council would act as a "surrogate enforcer" on behalf of the ICC to whether it would instead intervene on Sudan's behalf by bringing the wheels of international justice to a halt. As the ICC pre-trial chamber quietly considered Moreno-Ocampo's request for an arrest warrant, Sudan and its regional advocates-the African Union and the Arab League-called on the Security Council, the court of last resort, for an Article 16 suspension of the al-Bashir case.

Sudan's bid for an Article 16 suspension has proven difficult, given the power of any of the five permanent members of the Security Council to block such a move. Moreover, for the Council to suspend the case could be interpreted as a repudiation of its original justification for referring the Darfur situation to the Court. The Council's referral was premised upon the assumption that international justice would help counter the threat to international peace and security posed by the inhuman violence in Darfur. But a decision to suspend the al-Bashir case would require the Council, in effect, to find that the ICC's case vis-à-vis Darfur posed a threat to peace and security.

For the ICC's predecessors, the International Criminal Tribunals for the Former Yugoslavia and Rwanda, such direct Security Council intervention is disallowed because it would be viewed as blatant obstruction of international justice. But the ICC operates under different ground rules and a different conception of the proper relationship between the Security Council and the prosecutorial and judicial wings of the Court. In a compromise agreed to in the final days of the founding Rome conference, states adopted Article $16,{ }^{146}$ the provision in the Statute that permits the Security Council to suspend for renewable one-year periods any ICC case it deems a threat to international peace and security. That the Security Council is required to make such a finding regarding peace and security provides the incentive for targeted states as well as rebel groups to frame their assault against the ICC on the claim that international justice endangers peace.

As the ICC pre-trial chamber deliberated over the legal merits of the prosecutor's application for an arrest warrant in the second half of 2008, Sudan called on the Security Council to heed the alleged disastrous consequences of allowing the ICC to proceed. However, by the end of 2008, there were signs of growing support among key Council members to refrain from suspending the al-Bashir case. ${ }^{147}$ There were also indications that some of Sudan's African and Arab allies had grown wary of Khartoum's truculence, particularly its refusal to engage the Court by not seriously pursuing credible domestic war crimes prosecutions as an alternative to ICC trials. ${ }^{148}$ Instead, the al-Bashir government maintained its campaign of fear, telegraphing to the world how much it stands to lose by not intervening to stop the ICC's judicial intervention in Sudan. In this campaign, Khartoum has skillfully played the "instability card," 149 painting grim scenarios in which an unaccountable and remote ICC would reignite the Darfur crisis and perhaps even the dissolution of Sudan itself. The prospect that the ICC could trigger a deterioration of the Darfur crisis-even if the violence was cynically driven by Khartoum to substantiate its claims that justice undermines peace-has been Sudan's most potent weapon in its fight with the ICC. While 
Sudan has not won an Article 16 suspension of the al-Bashir case, it has nevertheless undermined the standing of the Court. This is punctuated by the African Union statement of early July 2009 that calls on African states not to cooperate in arresting the Sudanese president. The backlash against the ICC-which some ICC supporters have feared could lead African State Parties to withdraw from the Court-points to the inherent risks in targeting an African head of state.

Even as Moreno-Ocampo's announced intention to prosecute al-Bashir greatly increased the ICC's profile and thrust the tarnished Sudanese president on the defensive, the chief prosecutor has found himself facing accusations of spoiling the prospects of peace in Darfur. It is in this highly politicized context that Moreno-Ocampo and his advocates in the international human rights community have sought to gain the upper hand by reframing the peace versus justice debate in their own favor. The struggle with Khartoum is not only about fulfilling the Court's central mission of prosecutions in its most high-profile situation. Also at stake is the ICC's legitimacy and viability as a permanent court of global justice. Whether or not the Security Council invokes Article 16, the al-Bashir case will be closely watched by present and future targeted states and rebel groups looking to win reprieves from international justice. Central to the chief prosecutor's campaign for cooperation in Sudan has been to argue for the indispensable role that the ICC can play, in conjunction with a resolute international community, in ameliorating the ongoing humanitarian crisis in Darfur. Giving no ground to his critics, Moreno-Ocampo has argued that it is a pragmatic imperative for the world to press for the arrest of Sudanese suspects most responsible for atrocities-atrocities that pose an enduring threat to stability in the region and to the survival of entire communities in Darfur. ${ }^{150}$

In his quest for Sudan's cooperation and Security Council backing, MorenoOcampo has presented himself as a determined, uncompromising prosecutor willing to challenge state sovereignty. In this respect, the chief prosecutor we see in the Darfur situation stands in marked contrast to the same chief prosecutor who has been careful to avoid targeting state authorities in Uganda, Congo, and the Central African Republic. When it comes to Darfur, Moreno-Ocampo has warned the Security Council that "inaction and business as usual" 151 are acts that help perpetuate the crimes. But even as he stands apart from the Security Council-going as far as to cast himself as its moral conscience-the prosecutor has emphasized that targeting Sudanese suspects and campaigning for state cooperation is not the work of a rogue prosecutor, but a responsibility mandated to him by the Council itself. "The Security Council requested judicial intervention," Moreno-Ocampo reminded the Council in December 2008, as a prelude to calling for decisive action in seeking al-Bashir's arrest. It remains to be seen whether the Security Council heeds or abandons its own request for international justice.

\section{Acknowledgments}

The author is grateful to Harvey Peskin, Neva Peskin, and three anonymous reviewers for their helpful comments on earlier drafts of this manuscript.

\section{Notes}

1. In a 1995 speech to the UN General Assembly, ICTY President Antonio Cassese said, "Our tribunal is like a giant who has no arms and legs. To walk and work he needs artificial limbs. These artificial limbs are the state authorities." Address to the UN General Assembly, UN Doc. A/50/PV.52 (7 November 1995). 
2. Victor Peskin, International Justice in Rwanda and the Balkans: Virtual Trials and the Struggle for State Cooperation (New York: Cambridge University Press, 2008): 12.

3. Ibid., 7.

4. Pre-Trial Chamber 1 is assigned to the Darfur situation.

5. For instance, see Luis Moreno-Ocampo, "Statement to the United Nations Security Council on the Situation in Darfur, the Sudan, pursuant to UNSCR 1593 (2005)" (3 December 2008), http://www.iccnow.org/documents/iccProsecutorStatementUNSC_3dec08.pdf.

6. Tsegaye Tadesse, "ICC Genocide Charge Sought for Sudan's Bashir," Reuters, 7 July 2009.

7. UN Security Council Resolution 1593, UN Doc. S/RES/1593 (31 March 2005).

8. On 6 June 2005, Moreno-Ocampo announced his decision to officially begin an investigation into the Darfur situation.

9. Fieldwork interviews with ICC officials, The Hague, June and November 2007.

10. Alex de Waal, "Darfur, the Court and Khartoum: The Politics of State Non-Cooperation," in Courting Conflict? Justice, Peace and the ICC in Africa, ed. Nicholas Waddell and Phil Clark (London: Royal African Society, 2008), 30.

11. "Ending Sudan's Impunity," The Economist, 3 March 2007, 54.

12. Moreno-Ocampo determined that these charges were admissible at the ICC because Sudanese courts were not investigating Harun and were pursing Kushayb for different crimes.

13. See Warrant of Arrest for Ahmad Harun, Pre-Trial Chamber I (27 April 2007), http:// www.icc-cpi.int/library/cases/ICC-02-05-01-07-2_English.pdf; and Warrant of Arrest for Ali Kushayb, Pre-Trial Chamber 1 (27 April 2007), http://www.icc-cpi.int/library/cases/ ICC-02-05-01-07-3_English.pdf.

14. Ibid.

15. "Sudanese Justice Minister Rejects ICC Indictments on Darfur," Sudan Tribune, 11 February 2008, http://www.sudantribune.com.

16. "Sudan War Crimes Suspect Says Charges 'Political,"” Agence France-Presse, 28 February 2007, http://www.afp.com/afpcom/en/.

17. Statement of Elfatih Mohammed Erwa, Sudanese Ambassador to the UN, 5158th meeting of the Security Council, UN Doc. S/PV.5158 Provisional (31 March 2005).

18. Ibid.

19. Sudan criticized the provision in the Security Council's referral of the Darfur situation to the ICC that exempted non-State Parties, such as the United States, from the jurisdiction of the Court for any violations of international humanitarian law committed in Sudan. See Security Resolution 1593.

20. Marlise Simons, "Rebel Leader Becomes First Suspect in Darfur Violence to Appear in Hague Court," New York Times, 19 May 2009, A10.

21. As of April 2009, the ICC chief prosecutor has opened preliminary investigations in Kenya, Cote d'Ivoire, Colombia, Georgia, and Afghanistan.

22. For example, see William Schabas, "Prosecutorial Discretion v. Judicial Activism at the International Criminal Court," Journal of International Criminal Justice 6 (2008): 73161; Phil Clark, "Law, Politics and Pragmatism: The ICC and Case Selection in the Democratic Republic of Congo and Uganda," in Courting Conflict? Justice, Peace and the ICC in Africa, ed. Nicholas Waddell and Phil Clark, 37-44 (London: Royal African Society, 2008).

23. Fieldwork interview with ICC official, The Hague, December 2008.

24. Fieldwork interviews with ICC observers and diplomats, The Hague, June 2009.

25. "AU Nations 'Will Not Arrest Bashir,'” Al Jazeera (English), 4 July 2009, http://english. aljazeera.net/news/africa/2009/07/200973195375587.html.

26. Ibid.

27. Fieldwork interviews with international human rights activists, The Hague, June 2009.

28. Ibid. 
29. Tesfa-alem Tekle, “Africa Urges Suspension of ICC Indictment Process against Sudan's Bashir," Sudan Tribune, 22 July 2008, http://www.sudantribune.com/.

30. Michael Slackman and Robert F. Worth, "Setting Aside Divisions, Arab Leaders Rally behind Sudan's President at Meeting," New York Times, 31 March 2009, A5.

31. For a listing of the 110 States Parties, see http://www.icc-cpi.int/Menus/ASP/states+parties/ The+States+Parties+to+the+Rome+Statute.htm.

32. "AU to Shelter Bashir from War Crimes Warrant: Delegates," Agence France-Presse, 3 July 2009, http://www.afp.com/afpcom/en/.

33. Andrew Heavens, "AU Ruling Means Bashir Can Travel in Africa: Sudan," Reuters, 4 July 2009.

34. During the Libya summit meeting, Chad and Ghana reportedly resisted the AU statement regarding the Bashir case. See "AU Agree To Protect Sudanese President from Arrest," Sudan Tribune, 4 July 4 2009, http://www.sudantribune.com/. A week after the summit, the Ugandan government appeared to distance itself from the AU position on the Bashir case by issuing a statement reaffirming its commitment to the Rome Statute. However, the Ugandan statement did not explicitly refute the AU statement. See "Uganda Says Committed to ICC as Sudan's Bashir Plans a Visit," Sudan Tribune, 11 July 2009, http://www.sudantribune.com/.

35. "Botswana Condemns AU Resolution on Sudan's Bashir," Reuters, 7 July 2009.

36. See statement of Elfatih Mohammed Erwa, 31 March 2005.

37. "Sudan Demands the Arrest and Prosecution of the ICC Prosecutor," Sudan Tribune, 6 April 2008, http://www.sudantribune.com/.

38. Colum Lynch, "U.N. Fears Embattled Sudan Taking Aim at Peacekeepers," Washington Post, 20 July 2008, http://www.washingtonpost.com/.

39. As quoted in Luis Moreno-Ocampo, Statement to the UN Security Council (3 December 2008).

40. "Sudan President Says Only DNA Test Can Prove Rape in Darfur," Sudan Tribune, 20 October 2008, http://www.sudantribune.com/.

41. Victor Peskin, "Caution and Confrontation in the International Criminal Court's Pursuit of Accountability in Uganda and Sudan," Human Rights Quarterly 31 (2009): 676.

42. Ibid.

43. Colum Lynch, "Sudan's 'Coordinated' Genocide in Darfur is Over, U.S. Envoy Says," Washington Post, 18 June 2009, http://www.washingtonpost.com/.

44. Fieldwork interview with European diplomat, Brussels, May 2008.

45. "Sudanese Minister Threatens Action against International Court Proponents," text of report by London-based newspaper Al-Hayat, supplied by BBC Worldwide Monitoring, 1 March 2007.

46. "Sudan Demands the Arrest and Prosecution of the ICC Prosecutor," Sudan Tribune, 6 April 2008, http://www.sudantribune.com/.

47. Louis Charbonneau, "Prosecutor Accuses Sudanese State of Darfur Crimes," Reuters, 5 June 2008.

48. Neil MacFarquhar and Marlise Simons, "Sudan's Leader Scolds the West and Assails Aid Groups," New York Times, 6 March 2009, A10.

49. Lydia Polgreen, "Sudanese Protest War Crimes Case against President at Scripted Rally in Capital," New York Times, 14 July 2008, A10.

50. Human Rights Watch, World Report 2009-Sudan, 14 January 2009, http://www.unhcr. org/refworld/docid/49705f8f64.html.

51. Ibid.

52. “Arab League Chief Visits Sudan To Present Plan on Stalling ICC Indictments," Sudan Tribune, 21 July 2008, http://www.sudantribune.com/; "AU Report to UNSC Say [sic] Sudan Serious about Combating Impunity," Sudan Tribune, 7 October 2008, http://www. sudantribune.com/.

53. Ibid. 
54. Jeffrey Gettleman, "Sudan Arrests Militia Chief Facing Trial in The Hague," New York Times, 14 October 2008, A10.

55. Human Rights Watch, World Report 2009-Sudan.

56. Moreno-Ocampo, Statement to the UN Security Council (3 December 2008).

57. “Sudanese Officials Tell France 'No Dealings with ICC,'” Sudan Tribune, 9 October 2008, http://www.sudantribune.com/.

58. Fieldwork interview with ICC official, The Hague, December 2008.

59. "Former U.S. Special Envoy to Sudan Warns against ICC Darfur Indictments," Sudan Tribune, 27 June 2008, http://www.sudantribune.com/.

60. Andrew S. Natsios, "Beyond Darfur: Sudan's Slide toward Civil War," Foreign Affairs (May/June 2008), http://www.foreignaffairs.org/20080501faessay87306/andrew-s-natsios/ beyond-darfur.html.

61. Golzar Kheiltash and Julia Fitzpatrick, "No Peace without Justice: U.S. Must Cooperate with the International Criminal Court on Darfur," Briefing Paper (Washington, DC: Citizens for Global Solutions, 2006), 5.

62. These arguments are drawn from Nick Grono and David Mozersky, "Sudan and the ICC: A Question of Accountability,” Open Democracy (31 January 2007), http://www.opendemocracy. net/democracy-africa_democracy/sudan_icc_4301.jsp.

63. Peskin, International Justice in Rwanda and the Balkans, 11.

64. Fieldwork interview with Western diplomat, The Hague, November 2007.

65. Fieldwork interview with international human rights official, Brussels, May 2008.

66. Report of the International Commission of Inquiry on Darfur to the United Nations Secretary-General, Pursuant to Security Council Resolution 1546 of 18 September 2004, UN Doc. S/2005/60 (25 January 2005), http://www.un.org/News/dh/sudan/com_inq_darfur. pdf.

67. Colin Powell, testimony before the Senate Foreign Relations Committee, Washington, DC, 9 September 2004.

68. For instance, see Samuel Totten and Eric Markusen, eds., Genocide in Darfur: Investigating the Atrocities in the Sudan (New York: Routledge, 2006); Gerard Prunier, Darfur: A 21st Century Genocide, 3rd ed. (Ithaca, NY: Cornell University Press, 2008); Julie Flint and Alex de Waal, Darfur: A New History of a Long War (London: Zed Books, 2008); John Hagan and Wenona Rymond-Richmond, Darfur and the Crime of Genocide (New York: Cambridge University Press, 2009).

69. For an analysis of the ways in which Moreno-Ocampo has adopted an adversarial pursuit of cooperation in Uganda and Sudan, see Peskin, "Caution and Confrontation," 655-91.

70. Marlies Glasius, The International Criminal Court: A Global Civil Society Achievement (New York: Routledge, 2005), 47-60.

71. Fieldwork interviews with Western diplomats and international NGO officials, The Hague, June and November 2007; Brussels, May 2008.

72. Schabas, "Prosecutorial Discretion v. Judicial Activism," 751-52.

73. Clark, "Law, Politics and Pragmatism," 43.

74. Benjamin N. Schiff, Building the International Criminal Court (New York: Cambridge University Press, 2008), 212.

75. Fieldwork interviews with ICC officials, The Hague, December 2008.

76. For instance, Schabas writes, "Prosecutions of only one side in the conflict seems to be the price of the self-referral strategy of the Office of the Prosecutor." See Schabas, "Prosecutorial Discretion v. Judicial Activism," 753.

77. Fieldwork interviews with representatives of international NGOs, Brussels, May 2008.

78. Fieldwork interviews with representatives of international human rights organizations, Brussels, May 2008; Antonio Cassese, "Is the ICC Still Having Teething Problems?" Journal of International Criminal Justice 4 (2006): 434-41.

79. Peskin, International Justice in Rwanda and the Balkans, 12, 239-43.

80. Fieldwork interview with NGO representative, Brussels, May 2008.

81. Fieldwork interview with Western diplomat, The Hague, June 2007. 
82. Prosecutor v. Harun, Warrant of Arrest for Ahmad Harun, ICC-02/05-01/07 (27 April 2007).

83. Fieldwork interview with Western diplomat, The Hague, November 2007.

84. Alex de Waal, "Darfur, the Court and Khartoum," 31.

85. Alex de Waal, "Justice and Peace: The ICC, Sudan, and the Crisis of Human Rights," African Arguments Online Blog, posted 5 March 2009, http://africanarguments.org/2009/ 03/the-icc-sudan-and-the-crisis-of-human-rights/.

86. See Julie Flint and Alex de Waal, "Case Closed: A Prosecutor Without Borders," World Affairs (Spring 2009), http://www.worldaffairsjournal.org/2009\%20-\%20Spring/fullDeWaalFlint.html.

87. Luis Moreno-Ocampo, "The Rome Statute and the International Center for Transitional Justice" (speech, International Center for Transitional Justice, New York, 20-21 May 2008), http://www.ictj.org/images/content/9/0/905.pdf.

88. Ibid.

89. Ibid.

90. Fieldwork interviews with Western diplomats, The Hague, June 2007; and with representatives of international human rights organizations, Brussels, 2008. See also Peskin, "Caution and Confrontation," 655-91.

91. Wasil Ali, "ICC Planned to Divert Plane of Darfur War Crimes Suspect," Sudan Tribune, 25 June 2008, http://www.sudantribune.com/; see also Louis Charbonneau, "International Prosecutor Is 'Terrorist'-Sudan Envoy,” Reuters, 11 June 2008.

92. Charbonneau, "International Prosecutor Is 'Terrorist'-Sudan Envoy."

93. "Sudan to Press Terrorism Charges against the ICC Prosecutor," Sudan Tribune, 25 June 2008, http://www.sudantribune.com.

94. Luis Moreno-Ocampo, "Statement to the United Nations Security Council pursuant to UNSCR 1593 (2005)" (5 December 2007), http://www.icc-cpi.int/NR/rdonlyres/1ADB9ADCD65B-441A-863D-1139C5E42ED7/277794/OTPST20071205UNSCLMOENG.pdf.

95. Luis Moreno-Ocampo, Statement to the UN Security Council (3 December 2008).

96. Moreno-Ocampo, "Statement to the United Nations Security Council on the situation in Darfur, the Sudan, pursuant to UNSCR 1593 (2005)" (5 June 2009), http://www.icc-cpi. int/NR/rdonlyres/8A4EAC94-694F-4365-90E4-862438D1731D/280453/ OTPSpeech05062009_Eng1.pdf.

97. Ibid.

98. Ibid.

99. Moreno-Ocampo, Statement to the UN Security Council (5 December 2007).

100. Moreno-Ocampo, Statement to the UN Security Council (3 December 2008).

101. Ibid.

102. Moreno-Ocampo, Statement to the UN Security Council (5 June 2009).

103. Statement of Jean-Marc de la Sablière, the French Ambassador to the UN, 5158th meeting of the Security Council, UN Doc. S/PV.5158 Provisional (31 March 2005).

104. UN Secretary-General Kofi Annan (Press Release), UN Doc. SG/SM/9797 AFR/1132 (31 March 2005).

105. It is important to note that in July 2008 the Security Council adopted a resolution that emphasized "the need to bring to justice the perpetrators of ... crimes and urging the Government of Sudan to comply with its obligations in this respect." However, this resolution did not explicitly mention Sudan's obligation to cooperate with the ICC. See Security Council Resolution 1828, UN Doc. S/RES/1828 (31 July 2008).

106. For instance, see Statement by the President of the Security Council, UN Doc. S/PRST/ 2007/15 (25 May 2007).

107. For instance, a 24 October 2007 Council statement on Sudan included the following sentence: "The Council also recognizes that due process must take its course." "Security Council Presidential Statement Calls for Cessation of Hostilities in Darfur as Weekend Peace Talks Date Approaches," UN Doc. SC/9156 (24 October 2007).

108. See Security Council Resolution 1769, UN Doc. S/RES/1769 (2007) (31 July 2007). 
109. Fieldwork interview with representatives of international human rights organizations, Brussels, May 2008.

110. "Braced for the Aftershock," The Economist, 7 March 2009, 66; Human Rights Watch, World Report 2009-Sudan. The lack of progress in deploying the peacekeeping mission has been attributed to Sudan's intransigence, insecurity, and UN bureaucracy. See Report of the Secretary-General on the Deployment of the African Union-United Nations Hybrid Operation in Darfur, UN Doc. S/2008/304 (9 May 2008); "The Genocide Continues," New York Times, 17 June 2008, A22.

111. Fieldwork interview with European Union diplomat, Brussels, May 2008.

112. Ibid.

113. Luis Moreno-Ocampo, Address to the Security Council (7 June 2007); Official communiqué of the 5688th (closed) meeting of the Security Council, UN Doc. S/PV.5688 (7 June 2007).

114. Official communiqué, ibid.

115. Statement of Ilya Rogachev, Russia's deputy permanent representative to the UN, 5789th meeting of the Security Council, UN Doc. S/PV.5789 Provisional (5 December 2007).

116. Fieldwork interviews with European Union officials and representatives of international human rights organizations, Brussels, May 2008.

117. Declaration by the Presidency on behalf of the European Union on the Anniversary of the referral of the situation in Darfur/Sudan to the ICC, Council of the European Union, 31 March 2008, http://www.consilium.europa.eu/ueDocs/cms_Data/docs/pressData/en/ cfsp/99624.pdf.

118. Luis Moreno-Ocampo, Address to the UN Security Council, 5 June 2008.

119. Security Council Presidential Statement, UN Doc. S/PRST/2008/21, unanimously adopted (16 June 2008).

120. Neil MacFarquhar, "U.S. Encourages a Court to Help Prosecute Sudan," New York Times, 6 June 2008, A10.

121. Fieldwork interview with ICC official, The Hague, December 2008.

122. "UN: Council Faults Sudan Inaction on War Crimes Suspects" (Press Release), Human Rights Watch, 16 June 2008, http://www.hrw.org/en/news/2008/06/15/un-council-faultssudan-inaction-war-crimes-suspects.

123. Louis Charbonneau, "UN Council Says Sudan Must Heed Court on Darfur," Reuters, 16 June 2008.

124. Council of the European Union, "General Affairs and External Relations," 10726/08 (Presse 177) (16 June 2008), http://www.eu2008.si/en/News_and_Documents/Council_ Conclusions/June/0616_GAERC-pr-EXTR.pdf.

125. Fieldwork interviews with ICC officials and international human rights advocates, The Hague, June and November 2007 and December 2008; Brussels, May 2008.

126. Mieczyslaw P. Boduszynski and Kristina Balalovska, "Between a Rock and a Hard Place: Croatia, Macedonia, and the Battle over Article 98," Problems of Post-Communism (2004): 18-28.

127. Warren Hoge, “U.S. Lobbies U.N. on Darfur and International Court," New York Times, 29 January 2005 , A5.

128. Ibid.

129. For instance, see Samantha Power, "Court of First Resort," New York Times, 10 February 2005, Op-ed.

130. The United States, China, Brazil, and Algeria abstained. The remaining eleven countries on the Security Council voted in favor of referring the Darfur situation to the ICC.

131. For an analysis of the American-based Darfur movement, see Rebecca Hamilton and Chad Hazlett, "'Not on Our Watch': The Emergence of the American Movement for Darfur," in War in Darfur and the Search for Peace, ed. Alex de Waal (Cambridge, MA: Harvard University Press, 2007), 337-66. 
132. Nora Boustany, "Official Floats Possibility of Assistance to Hague Court," Washington Post, 12 June 2007, A20.

133. “U.S. Toughens Stance against Freezing Indictment of Sudan President," Sudan Tribune, 4 August 2008, http://www.sudantribune.com/.

134. Prunier, Darfur: A 21st Century Genocide, 178.

135. "China Key Arms Supplier to Human Rights Abusers," Inter Press Service, 6 August 2008; Maggie Farley, "China, Russia Faulted for Sudan Arms Sales," Los Angeles Times, 9 May 2007, http://www.latimes.com; "The Facts: China's Arms Sales to Sudan" (Fact Sheet), Human Rights First, http://www.stoparmstosudan.org/pages.asp?id=22.

136. Prunier, Darfur: A 21st Century Genocide, 178.

137. Ibid., 179.

138. Christine Chaumeau, "Beijing's Calculated Prudence," in ICC in 2006: Legal and Political Issues Surrounding the International Criminal Court (Paris: International Justice Tribune, 2006), 109.

139. "China in a Deep Dilemma as Sudan's Bashir Faces Charges," Reuters / Sudan Tribune, 15 July 2008, http://www.sudantribune.com/.

140. “U.S. Toughens Stance," Sudan Tribune, 4 August 2008, http://www.sudantribune.com/.

141. Andrew Heavens, "China Urges Deferral of Bashir War Crimes Case," Reuters, 7 January 2009.

142. Ibid.

143. Andrew Heavens, "China Urges Deferral of Case."

144. Farley, "China, Russia Faulted."

145. "Russia Concerned by UN Resolution on Sudan President Indictment," Sudan Tribune, 2 August 2008, http://www.sudantribune.com/.

146. Glasius, The International Criminal Court, 54.

147. Neil MacFarquhar, "Council Backs Idea to Indict Sudan Leader," New York Times, 4 December 2008, A12.

148. Fieldwork interview with ICC official, The Hague, December 2008.

149. Peskin, International Justice in Rwanda and the Balkans, p. 91.

150. Moreno-Ocampo, Statement to the UN Security Council (3 December 2008).

151. Ibid. 